\title{
Defining Identification: A Theoretical Look at the Identification of Audiences With Media Characters
}

\author{
Jonathan Cohen \\ Department of Communication \\ University of Haifa
}

\begin{abstract}
In this article I argue that although the notion of identification with media characters is widely discussed in media research, it has not been carefully conceptualized or rigorously tested in empirical audience studies. This study presents a theoretical discussion of identification, including a definition of identification and a discussion of the consequences of identification with media characters for the development of identity and socialization processes. It is suggested that a useful distinction can be made between identification and other types of reactions that media audiences have to media characters. A critical look at media research involving identification exposes the inherent conceptual problems in this research and leads to hypotheses regarding the antecedents and consequences of identification with media characters. The importance of a theory of identification to media research and communication research, more broadly, is presented.
\end{abstract}

When reading a novel or watching a film or a television program, audience members often become absorbed in the plot and identify with the characters portrayed. Unlike the more distanced mode of reception - that of spectatorship_identification is a mechanism through which audience members experience reception and interpretation of the text from the inside, as if the events were happening to them. Identification is tied to the social effects of media in general (e.g., Basil, 1996; Maccoby \& Wilson, 1957); to the learning of violence from violent films and television, specifically (Huesmann, Lagerspetz, \& Eron, 1984); and is a central mechanism for explaining such effects. As Morley (1992) said: "One can hardly imagine any television text having any effect whatever without that identification" (p. 209). The most promi-

Requests for reprints should be sent to Jonathan Cohen, Department of Communication, University of Haifa, Mt. Carmel, Haifa, Israel, 31905. E-mail: jcohen@research.haifa.ac.il 
nent studies of media reception (e.g., Liebes \& Katz, 1990; Press, 1989; Radway, 1983) as well as several studies of media effects (e.g., Huesmann et al., 1984; Maccoby \& Wilson, 1957; Sheehan, 1983; Wiegman, Kuttschreuter, \& Baarda, 1992) accorded identification an important role in the effects of media.

Huesmann et al. (1984) found that identifying with aggressive characters on TV increased the learning of aggressive behavior by children. Basil (1996) found that identification with celebrities who were promoting health messages increased the adoption of these messages. Maccoby and Wilson (1957) found that children remembered more of the actions and speech of characters with whom they identified. Ethnographic audience studies found that when asked to discuss their reactions to shows, TV viewers will often focus on their feelings and reactions to characters, including mentions of strong identification with characters (e.g., Liebes \& Katz, 1990). Finally, identification is important because of its contribution to the development of self-identity. As self-identity is related to our perception of others and how they view us, media images are linked to self-identity (e.g., sexual identity is linked to beliefs about sex roles). Identifying with media others allows us to experience social reality from other perspectives and, thus, shapes the development of self-identity and social attitudes (Erikson, 1968).

It is little surprising, therefore, that various communication theories have explored identification. Textual theories have proposed to uncover the ways certain features of texts promote audience identification (Wilson, 1993). Theories of media effects see identification as increasing the association between exposure and impact (e.g., Basil, 1996). For theories of active involvement, identification is an important motivation for, and outcome of, media exposure (e.g., Ang, 1982/1985). Finally, theories of media reception point to the possibility of varying the target and intensity of audience identification as a function of the social and psychological position of the audience vis-à-vis the text (e.g., Liebes \& Katz, 1990).

Although identification plays a major role in media research, the attempts to conceptualize the nature of identification and the theoretical treatment of this concept have been less satisfactory. From the reviews of the literature on identification with film and television characters, it is evident that identification is understood in a variety of ways by different theorists and that this confusion has inhibited the development of a comprehensive theory of identification and its consequences. In this exploration of the notion of identification, the following three questions are addressed:

1. What exactly is identification with media characters?

2. What are the different forms of engagement with media characters or responses to such characters by audience members that are sometimes confused with identification (e.g., parasocial interaction [PSI], imitation, and modeling)?

3. What can we conclude from existing research about the causes and consequences of identification? 


\section{THEORETICAL CONTEXT}

The conceptual and theoretical roots of identification emerged from psychological notions of child identification. Through studies of the importance of identification for the development of social and personal identities and the risks of weak childhood identification with adults, the concept has been adapted to study identification with film and then television characters (van Beneden, 1998). Identification, according to this tradition, is a psychological phenomenon that is part of the developmental process.

\section{Identification, Imagination, and Consciousness}

Freud (1940/1989, p. 76) viewed identification as a nonconscious imaginative process that results from psychological pressures due to the Oedipal complex, compensation for the loss of object-love, jealousy, or mortification. Identification with one's parents was theorized as the process by which parents (their identity, values, etc.) are incorporated into the self and become part of the superego. Adorno, Frenkel-Brunswik, Levinson, and Sanford (1950) proposed that incomplete identification with parents during childhood may lead to the development of authoritarian personality traits later in life.

In extending the Freudian (1940/1989) notion of identification, Wollheim (1974) provided a clearer idea of the nature of identification. Wollheim distinguished identification from imitation: Identification has an internal component, whereas imitation is external and behavioral. Identification, according to Wollheim, involves imagining being someone else and imagining behaving like someone else. Using drama as a metaphor, Wollheim explained:

In effect what we do when we identify with another is that we write a part for ourselves, based upon the other, in the hope that, when we act it to ourselves, we shall be carried away by the performance. (p. 191)

Identification requires that we forget ourselves and become the other- that we assume for ourselves the identity of the target of our identification. For Wollheim, the target of identification was not limited to parents but may be any other person or character we can imagine.

A further extension of this concept was offered by Bettelheim (1943), who used the concept of identification in his description of coping mechanisms used by concentration camp inmates. In his writing, he discussed identification with the aggressor, in which prisoners use identification as a survival mechanism. Identification with aggressors is manifest when, to survive in an otherwise unbearable situation, prisoners internalize their captors' views of reality, attitudes, or beliefs. Thus, for Bettelheim (1943), identification does not require actively or willfully taking on the 
identity of the other but, rather, sharing their perspective and internalizing their view of the world. Bettelheim (1976) also used the concept of identification when he discussed the importance of children's tales to child development. He argued that by identifying with the hero of a tale, children psychologically experience the triumph of good over evil and learn that being good pays. In sum, according to Freud (1940/1989), Wollheim (1974), and Bettelheim (1943, 1976), identification is an imaginative experience in which a person surrenders consciousness of his or her own identity and experiences the world through someone else's point of view. Identification leads to the (temporary) adoption of an external point of view and to viewing the world through an alternative social reality. The varying intensity of identification reflects the extent to which one exchanges his or her own perspective for that of another and is able to forget him- or herself.

Although identification involves imagination, it plays an important part in shaping very real aspects of society. Identification is crucial to the socialization of children and the development of personal and social identities throughout the life cycle (Mead, 1934). Understanding identification with other people we encounter, both in direct and mediated situations as part of the process by which people form personal and group identities, introduces a broader context to theorizing about identification.

\section{Identification, Identity, and Socialization}

The ability to identify with others develops early in life and is a fundamental social ability (Erikson, 1968). When distinguishing play from game, Mead (1934) explained that, as opposed to the solitary nature of play, participating in a game requires that a child anticipates what others will do in response to his or her actions. By doing so, the child practices the ability to take on the perspectives of others, which eventually allows him or her to internalize the perspective of the generalized other, that is, to identify with a community or group. Particularly relevant to this discussion is that Mead's work tied identification with the notion of group identity. Identification with a group magnifies the feelings of superiority, and, unlike the norms against explicitly asserting personal superiority in public, belonging to a superior group is a legitimate way to assert self-superiority (Tajfel, 1979).

Erikson (1968) argued that the link between identification and identity is most crucial during adolescence when identification shifts from parents to peers and a more stable personal identity is formed. By identifying with others and imitating certain characteristics of others, the adolescent builds his or her identity:

Individually speaking, identity includes, but is more than, the sum of all successive identifications of those earlier years when the child wanted to be, and often was forced to become, like the people he depended on. Identity is a new product, which now meets a crisis to be solved only in new identifications with age mates and leader figures outside the families. (p. 87) 
According to Mead (1934) and Erikson (1968), then, identification is a normal part of development that allows children and adolescents to develop into adults. Children and adolescents identify with both people and characters and try on alternative ideas, images, attitudes, and identities. From this perspective, it is easy to understand the concerns of parents and educators when adolescents are surrounded by virtual "peers" from MTV or the FOX network serials. If identification involves internalization, it is likely that repetitive internalization of powerful and seductive images and alternative identities of media characters may have some long-term effects. This is especially true for adolescents who are in the process of forming their own identity and are susceptible to influence by media characters. Even if this internalization for adolescents is merely temporary - a "trying on" of alternative roles-it may include some extreme behaviors that have grave impact on the social environment (Meyrowitz, 1994).

It is perhaps this function of identification - the chance for vicarious experience- that has attracted most attention by media scholars. Vicarious experience may take various forms: experiencing things we cannot, or have not yet had the chance to, experience in person (e.g., winning a million dollars on Who Wants to Be a Millionaire? [Gentile, 2000]); trying on alternative identities (e.g., being an Olympic athlete, gangster, brilliant scientist, or super model for a day); or otherwise adopting the goals, feelings, or thoughts imagined to be those of the target of our identification. Whether this vicarious experience results in overt behavior (dressing up like Madonna or practicing a Michael Jordan jump shot) or takes on a more purely imaginative form, it is this vicarious experience that makes identification central. Through identification with characters in books, films, and television, we extend our emotional horizons and social perspectives.

Even though the importance of identification and vicarious experience to media theory is accepted, the theoretical basis for the study of identification with media characters has been largely intuitive. Furthermore, the study of identification within media studies has focused on explaining whom audiences identify with and what the consequences of this identification are, but it has failed to clearly articulate the nature of identification. Thus, identification has often been confused with similar concepts, such as parasocial relationships and fandom.

Within media studies, identification with media characters has generally been understood to denote feelings of affinity, friendship, similarity, and liking of media characters or imitation of a character by audience members. For example, Liebes and Katz (1990) distinguished between three types of reactions toward characters: liking, being like (similarity), and wanting to be like (modeling). Although they recognized multiple possible responses to media characters based on these three dimensions, they argued that these responses are all part of one psychological variable: identification. In a later extension of this discussion, Liebes (1996) further distinguished nine possible responses and how they make viewers of TV soap operas feel about themselves, but this discussion did not explicate the relationship be- 
tween liking, similarity, and imitation, on one hand, and identification (defined as empathy or feeling as if one was the character), on the other hand. Thus, it remains unclear whether these three possible responses are components of identification, whether they are all necessary, or sufficient conditions for identification (or all of these), or how such a conception of identification relates to earlier uses of the term (e.g., Freud, 1940/1989). Media studies, then, have failed to develop a clear definition of identification and specify its relationship with concepts of audience involvement with media characters.

\section{UNDERSTANDING IDENTIFICATION WITH MEDIA CHARACTERS}

Whereas operational definitions of identification have generally used indicators of attitudes and emotions toward characters as measures of identification, theoretical treatments of identification have suggested that identification is a more primary and internal process. For example, Livingstone (1998) described identification as imagining being in someone else's shoes and seeing the world through his or her eyes. According to this definition, identification should be seen as determining the audience member's basic position vis-à-vis the text, a position from which he or she shapes his or her view of the characters and events, and from which his or her emotional and cognitive disposition toward the characters and text develop (Liebes, 1996). Furthermore, a comprehensive definition should include a sense of identification as an experience - as a state in which one adopts the goals and identity of a character. Finally, a satisfactory definition of identification should attempt to explain the relationship between identification and other ways that audiences relate to characters (e.g., attitudes and emotions).

There are many types of media characters: newscasters, sports figures, cartoon characters, fictional characters, game-show contestants, and others. Types of characters are linked to types of media texts, although these two typologies do not fully overlap. The combination of specific text and character type determines, in part, the reactions of audience members toward a character (Hoffner, 1996). Given the definition of identification described next, the concept best fits reactions toward fictional characters in narrative texts. This is not to say that identification is impossible with other types of characters, such as sports players, but simply that this sort of identification: (a) is less likely and (b) would probably be manifested in different ways. Thus, when discussing media characters, I focus primarily on fictional characters in comedy and drama.

Based on earlier psychological theories of identification (i.e., Freud, 1940/1989; Wollheim, 1974), identification with media characters may be usefully defined as an imaginative process invoked as a response to characters presented within mediated texts. Identification is fleeting and varies in intensity (Wilson, 1993), a sensation felt intermittently during exposure to a media message. While identifying with 
a character, an audience member imagines him- or herself being that character and replaces his or her personal identity and role as audience member with the identity and role of the character within the text. While strongly identifying, the audience member ceases to be aware of his or her social role as an audience member and temporarily (but usually repeatedly) adopts the perspective of the character with whom he or she identifies. Oatley (1994) argued that one of the important basis for identification is that the reader adopts the characters' goals, comprehends plot events in reference to these goals, and experiences the feelings that result from the interaction of these goals and the events that take place. Thus, happiness should result from events that promote the character's goals and anxiety from those that threaten the success of these goals. As Zillmann (1994) pointed out, in most cases, the knowledge of the audience member is not identical to that of the character (the audience member may know more or less than the character about what is happening, depending on the narrative structure), but this does not mean, he argued, that identification is impossible. Rather, identification means that the knowledge of the audience members is processed from the character's perspective and is transformed into empathic emotions.

Unlike conceptions of identification that stress feelings and attributions about the character (i.e., sympathy and similarity), the current conceptualization of identification focuses on sharing the perspective of the character; feeling with the character, rather than about the character. This distinction echoes that made by Oatley (1999) between those readers who read as spectators, read about what happens to others, and those who identify with a specific character and experience the text from that character's perspective. The difference between spectatorship and identification is related to the psychological distance the reader maintains from the text and, in this sense, is similar to Wilson's (1993) notion of film viewing as a movement in and out of the film and of Fiske's (1989) contention that identification increases referential reception and decreases the distance needed for ideological and critical receptions of television.

This definition of identification as adopting the identity and perspective of a character helps clarify several attributes of identification. First, identification is defined not as an attitude, an emotion, or perception but, rather, as a process that consists of increasing loss of self-awareness and its temporary replacement with heightened emotional and cognitive connections with a character. Second, unlike a purely psychological theory of identification or a conception linked to sociological notions of identifying with social groups or leaders, identification is defined here as a response to textual features that are intended to provoke identification. Directors and writers create characters with whom audiences are meant to interact to enjoy books, films, or television programs. Unlike identification with parents, leaders, or nations, identification with media characters is a result of a carefully constructed situation. Thus, media studies of identification must account for the production of identification targets as well as the identification of audiences with them. Finally, it 
is important to note that identification is a response to communication by others that is marked by internalizing a point of view rather than a process of projecting one's own identity onto someone or something else.

Identification is a process that culminates in a cognitive and emotional state in which the audience member is aware not of him- or herself as an audience member, but rather imagines being one of the characters in the text. The process of identification may begin because of a production feature that brings the audience member to adopt a character's perspective (Wilson, 1993), an audience member's fondness for a specific character (Cohen, 1999), or a realization that a similarity exists between the audience member and a character (Maccoby \& Wilson, 1957). These lead to a psychological merging (Oatley, 1999) or attachment, in which the audience member comes to internalize the characters' goals within the narrative. The audience member then empathizes with the character and adopts the character's identity. As the narrative progresses, the audience member simulates the feelings and thoughts appropriate for the events that occur. Identification may be ended or interrupted when the audience member is made aware of him- or herself through an external stimuli (e.g., the phone rings), a textual stimuli (e.g., a change of camera angle or a direct reference to the reader), or the end of the story. Outcomes of identification may include increased liking or imitation but can also include negative feelings. Identifying with extremely negative characters who are evil or very violent may evoke some understanding or even sympathy for them during reading or viewing but strongly identifying with such a character is likely to cause dissonance, guilt, or even fear.

Following the definition provided previously and to further clarify the concept of identification, it may be helpful to compare it with other ways of describing reactions toward media characters or the relationships that audiences develop with them. As mentioned earlier, it is partly the lack of clear conceptual distinctions between identification and other audience-character processes that has inhibited theoretical development.

\section{DISTINGUISHING OTHER AUDIENCE RESPONSES TO MEDIA CHARACTERS FROM IDENTIFICATION}

Identification is but one of the many ways in which audience members react to people in the media (Hoffner \& Cantor, 1991). An audience member may respond by liking or disliking characters, feeling close to them (affinity; Newton \& Buck, 1985; Newton, Buck, \& Woelfel, 1986), finding similarities or differences between the characters and themselves (similarity; Reeves \& Miller, 1978), finding the characters sexually or romantically attractive (attachment; Steever, 1994), developing PSI with them (Horton \& Wohl, 1956), or desiring to imitate them (imitation; Hoffner, 1996). It is beyond the scope of this article to define each of these types of responses carefully; rather, it is necessary to distinguish identification from the other types of reactions and relationships. Table 1 summarizes the major distinc- 
TABLE 1

Comparing Identification With Similar Concepts

\begin{tabular}{|c|c|c|c|c|}
\hline & Identification & $\begin{array}{l}\text { Parasocial } \\
\text { Interaction }\end{array}$ & $\begin{array}{l}\text { Liking, Similarity, } \\
\text { Affinity }\end{array}$ & Imitation \\
\hline $\begin{array}{l}\text { Nature of } \\
\text { process }\end{array}$ & $\begin{array}{l}\text { Emotional and } \\
\text { cognitive, alters } \\
\text { state of awareness }\end{array}$ & $\begin{array}{l}\text { Interactional, } \\
\text { (para)social }\end{array}$ & Attitude & Behavior \\
\hline Basis & $\begin{array}{l}\text { Understanding and } \\
\text { empathy }\end{array}$ & Attraction & $\begin{array}{l}\text { Perceptions of } \\
\text { character and self }\end{array}$ & Modeling \\
\hline $\begin{array}{l}\text { Positioning of } \\
\text { viewer }\end{array}$ & As character & As self & As self & $\begin{array}{l}\text { As learner (self as } \\
\text { other) }\end{array}$ \\
\hline $\begin{array}{l}\text { Associated } \\
\text { phenomena }\end{array}$ & $\begin{array}{l}\text { Absorption in text, } \\
\text { emotional release }\end{array}$ & $\begin{array}{l}\text { Attachment to } \\
\text { character and text, } \\
\text { keeping company }\end{array}$ & Fandom, realism & $\begin{array}{l}\text { Learning, } \\
\text { reinforcement }\end{array}$ \\
\hline $\begin{array}{l}\text { Theoretical } \\
\text { roots }\end{array}$ & $\begin{array}{l}\text { Psychoanalysis, film } \\
\text { studies, social } \\
\text { psychology }\end{array}$ & $\begin{array}{l}\text { Psychology, } \\
\text { interpersonal } \\
\text { communication }\end{array}$ & Social psychology & $\begin{array}{l}\text { Experimental } \\
\text { psychology, social } \\
\text { learning theory }\end{array}$ \\
\hline
\end{tabular}

tions between identification and alternative conceptions of viewer responses to character.

\section{Identification and PSI}

As compared to PSI, identification lacks an interactional component because when identifying, one lacks an awareness of the self, and, therefore, the distinction between self and other-necessary for interaction-is missing. Identification with a television character is based on a psychological attachment between the viewer and a character (Cohen, 1997; Cole \& Leets, 1999), but rather then leading to interaction with the character, it leads to imagining being the character (Livingstone, 1998). Identification leads the audience member to experience the text as if he or she were inside the text, whereas for PSI to occur, one needs to retain his or her self-identity and interact with the character, thereby maintaining at least a minimal social distance (Horton \& Wohl, 1956). Identification requires extreme absorption in the text and involves an intense emotional experience, whereas PSI is a concept modeled to be similar to friendship and is increased by a direct address of the audience by the character (Auter, 1992). Finally, although both are psychological concepts, identification stems from psychoanalysis, whereas PSI is a concept rooted in the study of interpersonal communication (Horton \& Wohl, 1956).

Identification, Liking, Similarity, and Affinity

Identification is often related to audience perceptions of liking, similarity, and affinity to characters. However, these latter concepts describe attitudes or judgments 
that people make about characters based on their perceptions of the characters and of themselves as people. To compare or judge a character, one is required to activate his or her own psychological schemas and, hence, to be self-aware, whereas identification uses one's own psyche to imagine being someone else. To compare one's self, or to feel close to a character, one must be positioned outside the text as a spectator, rather than imagining one's self inside a textual reality. Liking and affinity are likely to increase fandom, and similarity is associated with a judgment of realism; identification, on the other hand, does not foster any judgments that require treating a character as external to the self.

\section{Identification and Imitation}

Finally, imitation is a behavioral concept rooted in learning theory that describes the acquisition of new behaviors based on observation of a model. When learning from characters on television, viewers position themselves as learners trying to both pay close attention to the learned behavior and assess the outcomes that follow (Maccoby \& Wilson, 1957).

With very few exceptions (e.g., Hoffner \& Buchanan, 1998; Liebes, 1996), the existing literature on the relationships between media audiences and media characters (whether or not the term identification is used) has failed to distinguish among various forms of audience responses to characters. Rather, researchers (e.g., Hoffner \& Cantor, 1991; Liebes \& Katz, 1990) lumped the different responses together, focusing entirely on the intensity of feelings toward the character and using various names and labels interchangeably: identification, PSI, and so forth. The lack of consistency in the conceptual use of identification by media scholars is further confounded by incompatibility of conceptual and operational definitions in empirical studies. Thus, even when scholars carefully defined identification in conceptual terms and went on to measure identification, the conceptual and operational definitions often did not match. While defining identification as "being in someone else's shoes," they measured liking, similarity, or desire to imitate (e.g., Liebes \& Katz, 1990; Maccoby \& Wilson, 1957).

\section{MEASURING IDENTIFICATION}

Although there is a frequently used scale that was developed to measure PSI (A. M. Rubin, Perse, \& Powell, 1985), no measure for identification with media characters has been devised. Thus, when trying to measure identification in empirical media studies, researchers have used several strategies:

1. Maccoby and Wilson (1957) were the first of many researchers to test the role of identification as a mediating variable between exposure to film and observa- 
tional learning. They theoretically defined identification as fantasizing oneself to be in the place of a character, and they measured identification through an additive scale of liking a character, wanting to be like a character, and feeling similar to a character. Others used a similar strategy (e.g., Eisenstock, 1984; Liebes \& Katz, 1990). This strategy overlooked the unique nature of identification and the differences between identification and other responses toward media characters.

2. Some scholars (e.g., Newton \& Buck, 1985; Newton et al., 1986; Reeves \& Miller, 1978) sidestepped the problem of operationalizing identification by using a more naturalistic approach and asked respondents to rank the distance they felt between them and television characters. This avoided the need to define the concept being measured and resulted in what seemed to be a subjective measure of affinity. A similar approach was to ask respondents directly whether they identified with a character and then to let respondents interpret the meaning of identification for themselves. In this approach, however, what exactly was being measured remains ambiguous.

3. From a more behavioral position, some researchers equated identification with actual imitation (e.g., Huesmann et al., 1984; Sheehan, 1983; Wiegman et al., 1992). This approach failed to distinguish between psychological and behavioral concepts. It is likely that identification sometimes leads to imitation, but, as argued previously, the two cannot be considered identical.

4. Some studies (e.g., Basil, 1996) measured identification using a wide range of questions, including liking, similarity, friendship, role modeling, and whether audience members thought they could work together with a celebrity. Thus, these researchers perceived identification not as a particular type of response toward a character but as a variable that measured the intensity of different types of positive feelings audience members had toward a character.

5. In literary studies of reader response, several ways to measure identification were used. Oatley (1999) and others used stream-of-consciousness methods; they asked readers to speak or write down their thoughts while they read stories. These thoughts and emotions were then analyzed to determine the degree of identification readers experienced. Miall and Kuiken (1995) devised the Literary Response Scale, a 7-factor, self-report scale for emotional and cognitive responses to reading that includes empathy, a major component of identification.

Because identification is an imaginative process that is characterized by an altered state of awareness, it is difficult to measure. However, although audience members who identify with media characters are not aware of doing so while identifying, this does not mean that they cannot recall it at a later time. After someone identifies with a character, he or she may be aware of having been deeply absorbed in the text and be able to assess the degree to which he or she empathized with the character and was able to understand and share the characters' feelings, goals, and perspective. 
In attempting to operationalize and measure identification, four dimensions are central. The first is empathy or sharing the feelings of the character (i.e., being happy; sad; or scared, not for the character, but with the character). The second is a cognitive aspect that is manifest in sharing the perspective of the character. Operationally this can be measured by the degree to which an audience member feels he or she understands the character and the motivations for his or her behavior. The third indicator of identification is motivational, and this addresses the degree to which the audience member internalizes and shares the goals of the character. Finally, the fourth component of identification is absorption or the degree to which self-awareness is lost during exposure to the text. Because identification is conceived as temporary and fleeting, it should be measured both in terms of intensity and frequency. The more someone is absorbed in the text, empathizes with and understands a character, and adopts his or her goals, the more he or she may be said to identify with that character.

Based on these dimensions and previous methods of measurement, the following items are suggested for measuring identification. Respondents may be asked to indicate their degree of agreement with the following statement, referring to a specific character in a specific TV show (these items could also be adapted for film or books):

1. While viewing program $X$, I felt as if I was part of the action.

2. While viewing program $X$, I forgot myself and was fully absorbed.

3. I was able to understand the events in the program in a manner similar to that in which character $\mathrm{X}$ understood them.

4. I think I have a good understanding of character X.

5. I tend to understand the reasons why character $X$ does what he or she does.

6. While viewing the show I could feel the emotions character $X$ portrayed.

7. During viewing, I felt I could really get inside character X's head.

8. At key moments in the show, I felt I knew exactly what character X was going through.

9. While viewing the program, I wanted character $X$ to succeed in achieving his or her goals.

10. When character X succeeded I felt joy, but when he or she failed, I was sad.

\section{Antecedents of Identification}

Because previous research has used different definitions of identification, it is difficult to assess the degree to which empirical evidence from these studies is applicable to identification as defined herein. However, the existing literature raises several questions and hypotheses regarding the variables that promote identification. One issue is the relative importance of textual features versus response variables in determining the likelihood of, choice of target for, and intensity of identification. 


\section{Technology Versus Audience}

Opposing theoretical positions have been suggested concerning the role of technology in defining the target of audience members' identification. Literary and film studies, focusing primarily on texts, suggest that texts offer heroes with whom audiences identify with through production technique. In films particularly, it is the camera that provides the viewpoint for the audience and determines the target of audience identification (Flitterman-Lewis, 1987). The identification of the film viewer is not with the characters but, rather, with the act of viewing itself that occurs through the camera, and only through the camera does the viewer identify with the hero of the film (Benjamin, 1969). Thus, according to these theorists, the identification of the viewer is determined by the director of a film through the positioning of the camera, his or her choice of shots, focus, and so on. The intense experience of cinema viewing - the dark theater, the back projection, the long shots, and cinematic techniques of establishing shots-provide the possibility of identifying with the camera telling the story or with the hero of the film chosen by the director to provide the primary point of view.

Similarly, novels are read alone; require undivided attention; and, therefore, allow for an intense reading experience. Literary reader response theory has posited several modes of response, ranging from spectatorship to identification. Oatley (1999) defined identification with literary characters as merging: "The meeting of identification is a species of empathy, in which we do not merely sympathize with a person, we become that person" (p. 446). He further contrasted film and literary novels and argued that, compared with the novel, films tend to favor the spectator role because of their visual nature, whereas novels and short stories are equally hospitable to both spectatorship and identification. Whereas films use camera angles to foster identification (Benjamin, 1969; Flitterman-Lewis, 1987), literary techniques, such as first-person narration (Oatley, 1999) and description of thoughts and feelings, are used to foster identification by inviting the reader to identify with the main protagonist. Alternatively, identification may be with the narrator who then serves as a spectator in reference to the characters in the story. Although this is the view of literary scholars, Oatley (1994) and film theorists (e.g., Houston, 1984) argued that film does invite identification but that TV viewing is passive and cannot elicit identification.

Because they have maintained that identification is technologically determined, film theorists (e.g., Houston, 1984) argued that television viewing cannot promote identification. Whereas back projection in cinema puts the viewer in line with the film's perspective by placing him or her in between the projector and the screen, television viewers sit opposite the direction of projection. As opposed to the one-camera film production or the literary narrator, the use of multiple cameras in television production does not provide a unified point of view with which viewers can identify. Film theorists (e.g., Houston, 1984) argued that because television 
viewing is an interrupted activity (i.e., shorter shots, commercial breaks, and shorter program formats), it does not allow for viewer identification. The domestic setting of television viewing, as opposed to the dark and quiet cinema, blends viewing with other domestic activities and, therefore, can offer only a "tease" rather than any real psychological satisfaction that comes through identification and, thus, only from film (Houston, 1984).

Of course, media scholars who study television put less stock in technologically based arguments (e.g., Meyrowitz, 1994; for an exception, see Lombard, 1995), and they have argued that television offers its viewers not just one, but many, characters to identify with. Television makes up for its interrupted form with the sheer volume of exposure and repetition. If film theorists focused on the uniqueness of film and its production to deny identification with television, social-science oriented television studies focused more on the audience who exhibited responses that suggested identification can be quite strong (Meyrowitz, 1994). Wilson (1993) explained the distinction between the two traditions as one between the structuralist paradigm and poststructuralist studies of film and television. In the former, identification is an effect produced by the text, whereas for the latter "'identification' involves mediation, an interpretation of the ideology articulated by textual subjects through the categories of understanding constituting the extra-textual viewer" (p. 63). Although there seems to be a basis for considering technological and production features as important for the study of identification, theories that have overemphasized technological determinants of audience response failed to consider the knowledge amassed by studies of active audiences. Typically, there has been little empirical evidence to substantiate the rich theoretical claims of technological effects. At the same time, substantial evidence has been gathered for active reception and variance in audience reactions to various media and texts and the importance of reception contexts. Further research is needed to delineate the ways in which technology, textual production, reception context, and profiles of individual audience members interact to shape the reactions to media characters.

Social-science oriented research regarding the antecedent factors related to audience-character relations leads to several hypotheses about factors that precede identification:

- Narrative genres should promote greater levels of identification than nonnarrative genres because they provide an alternative reality to which they transport the audience. Drama and comedy should promote more identification than television talk shows or news in which characters speak directly to audiences, constantly engaging them in their role as audience. It is precisely those features that promote PSI (Horton \& Wohl, 1956) that should limit identification and vice versa.

- Because identification requires audience members to imagine themselves as a character, similarity of audience members to characters should increase the likelihood of identification. However, this similarity may be based on a multitude of fac- 
tors other than demographic similarity of age, gender, or race. Indeed, iconic representations (i.e., animated characters) often elicit feelings of similarity by suggesting similarity of attributes (e.g., goofy or scared) or similarity of situation (being ridiculed like Dumbo or scared and dependent like Bambi). ${ }^{1}$

- As in interpersonal relationships, the duration of familiarity is important to the nature of the relationship between viewers and a character (R. B. Rubin \& McHugh, 1987). The longer an audience member is exposed to a character, the more likely he or she is to be able to imagine being that character.

- Similarly, it is hypothesized that perceived realism of a character will promote identification. As Press (1989) showed, perceived realism is a very important feature to television viewers in their reactions to texts in general and, more specifically, to characters. Realism, however, does not necessarily mean the similarity of a character's behavior to the real life of an audience member; it may be a similarity to a stereotype held by a viewer (e.g., a poor viewer) regarding the life of another social group (e.g., a rich character).

- Demographic and attitude similarity between viewer and character are also hypothesized to be predictors of viewer-character relations (Maccoby \& Wilson, 1957; Turner, 1993).

- Several psychological variables have also been linked to viewer-character relations. These include attachment models (Cohen, 1997; Cole \& Leets, 1999) and self-esteem (Turner, 1993).

Beyond technical production features or audience characteristics, there are attributes of a character that predict the development of audience relationships with them. These include, among others, physical attractiveness and favorable personality characteristics (Cohen, 1999; Hoffner, 1996; Hoffner \& Cantor, 1991).

\section{Identification and Consequences}

There is a theoretical basis for suggesting several consequences of identification. The link between possible media effects and identification is suggested not only because of identification's role in socialization, but also by theories of persuasion. Just as identification is one of the ways individuals create their own identities, identification can be used purposely by others as a means of social influence. Burke (1950) defined identification as cosubstantiality, a sharing of substance. He claimed that to persuade, a rhetorician must strive for a communality of motives with his or her audience, a sense that they share motives and values. Kelman (1961) viewed identification as one of three processes of social influence. Identification is used to persuade by making the source of a message, rather than the message itself, attractive.

\footnotetext{
${ }^{1}$ Thanks to the thoughtful reviewer who pointed this out to me.
} 
Identification is useful as a persuasion tactic because it can overcome the natural tendency to limit one's thoughts and feelings to a single perspective. By introducing other perspectives and persuading others to identify with them, new possibilities for understanding are opened that may result in attitude change. In advertising, celebrity appeals evoke identification, which may lead potential consumers to imagine themselves eating, drinking, or wearing an advertised product (Basil, 1996). Recent research has provided evidence of other psychological effects of identification with both individuals and groups in social behavior. For example, using dysphoric participants, Gleicher (1998) found that individuals felt more negative emotion when they identified with targets who were perceived as being less in control. Similarly, identifying with a winning team can boost self-esteem (Cialdini et al., 1976).

Given the evidence from social-psychological research about the importance of identification, it is easy to understand why media scholars have considered identification to be a process that mediates between exposure to media messages and persuasion. According to the elaboration likelihood model, identification increases involvement with messages, which, in turn, increases the elaboration of messages (Petty \& Cacioppo, 1984) and their potential persuasive effects. Another explanation for the effects of identification is that it increases the intensity of, and involvement with, the exposure to mediated texts and makes their meaning more memorable. According to learning theory (Bandura, 1986), identification can produce modeling and imitation because it provides a glimpse of "what if," and these glimpses are powerful predictors of future behavior. Wied, Zillmann, and Ordman (1994) also showed that the degree of empathic distress felt for a character was linked to the enjoyment of film. Because empathy is part of identification, it is likely that strong identification leads to greater enjoyment of media messages and, possibly, to greater impact.

Moreover, if high involvement with messages and greater elaboration also lead to a more critical stance, identification-because it involves the loss of self-awareness-is less likely to produce critical readings (Fiske, 1989). Rather, identification is likely to increase enjoyment, involvement, and intense emotional responses, but it is less likely to produce critical stances toward texts. It may be hypothesized that identification increases the persuasive and imitative effects of media on audiences.

\section{SUMMARY AND CONCLUSIONS}

Given the centrality of identification to media research, the need for a comprehensive theory of identification is clear. Such a theory must start with a definition of identification and measures that will enable researchers to accumulate evidence regarding the process of identification. The different concepts that have heretofore been equated with identification and used to measure it span behavioral, cognitive, and emotional concepts; encompass perceptions, attitudes, and desires; and include descriptions of a relational nature or of individual responses. 
The basic aim of this article is to define identification as one of several possible responses of media audiences to media characters. Identification is an imaginative process through which an audience member assumes the identity, goals, and perspective of a character. Identification is hypothesized to be promoted by technical production features and audience and character attributes and is expected to increase involvement with messages and decrease the chances of critical interpretation. More than being an attitude, judgment, or response to media characters (e.g., liking, similarity, affinity, or attraction), identification engages the audience member during reception.

The explication of the concept of identification is not only important in the narrow interest of studying media consumption, interpretation, and effects, but also, a more comprehensive theory of identification can play a role in several of the broader theoretical challenges facing communication studies. The first is the effort to integrate theories and concepts from the study of interpersonal communication into models of mass media (Cohen \& Metzger, 1998; A. M. Rubin \& Rubin, 1985, 1998). Most of the efforts to find common ground between theories of mass media and interpersonal communication have been directed toward exploring parasocial relationships as social relationships (R. B. Rubin \& McHugh, 1987). Although identification involves the merging of self and other, rather than the interaction between self and others, it is an important part of many close relationships and is an important mechanism through which people connect emotionally and cognitively with one another. Although identification with media characters is most characteristically a response to narratives, it is also a likely response to interpersonal contexts, such as stories heard around a campfire or at a slumber party, or in highly emotional interpersonal conversations, such as in support groups. Identification may also occur on a more permanent basis, such as when someone identifies with parents or a spouse, a social group, or even national symbols. Future research should explore the similarities and differences between identification in social situations and identification with media characters.

The further study of identification also promises to integrate the theorizing about texts and audiences. Distinguishing the different types of responses audience members have to characters requires analyzing the elusive moment of meeting of text and audience. It is fairly clear that different types of media and media texts promote different responses from audiences (e.g., film vs. television, print vs. visual, first-person vs. third-person narration, and narrative texts vs. nonnarrative texts), but it is equally probable that there is variance in the responses of different groups to a given text (differentiated by social groups and psychological variables). Thus, a comprehensive theory of identification will necessarily incorporate propositions about texts and audiences.

Clearly, it is premature to articulate a full theory of identification. This discussion of identification leaves many open questions and points to many directions of new research. The definition of identification that is offered here requires further 
elaboration and refinement as well as empirical tests of propositions regarding the factors leading to identification and the results of identification. As suggested previously, the development of empirical research also depends on the development of research measures for identification, for which examples are provided. The development of such measures will provide a new approach to the investigation of some of the most central issues in media studies and help explain the link between media, identification, social identities, and social relations.

\section{ACKNOWLEDGMENT}

I would like to thank Faith Gleicher for her helpful comments on an earlier draft of this work.

\section{REFERENCES}

Adorno, T. W., Frenkel-Brunswik, E., Levinson, D. J., \& Sanford, R. N. (1950). The authoritarian personality. New York: Harper.

Ang, I. (1985). Watching Dallas: Soap opera and the melodramatic imagination (D. Couling, Trans.). London: Meuthen. (Original work published 1982)

Auter, P. J. (1992). TV that talks back: An experimental validation of a parasocial interaction scale. Journal of Broadcasting and Electronic Media, 36, 173-181.

Bandura, A. (1986). Social foundations of thought and action. Englewood Cliffs, NJ: Prentice-Hall.

Basil, M. D. (1996). Identification as a mediator of celebrity effects. Journal of Broadcasting and Electronic Media, 40, 478-495.

Benjamin, W. (1969). The work of art in the age of mechanical reproduction. In H. Arendt (Ed.), Illuminations (pp. 217-252). New York: Schoken.

Bettelheim, B. (1943). Individual and mass behavior in extreme situations. Journal of Abnormal and Social Psychology, 38, 417-452.

Bettelheim, B. (1976). The uses of enchantment: The meaning and importance of fairy tales. New York: Knopf.

Burke, K. (1950). A rhetoric of motives. Berkeley: University of California Press.

Cialdini, R. B., Borden, R. J., Thorne, A., Walker, M. R., Freeman, S., \& Sloan, L. R. (1976). Basking in reflected glory: Three (football) field studies. Journal of Personality and Social Psychology, 34, 366-375.

Cohen, J. (1997). Parasocial relations and romantic attraction: Gender and dating status differences. Journal of Broadcasting and Electronic Media, 41, 516-529.

Cohen, J. (1999). Favorite characters of teenage viewers of Israeli serials. Journal of Broadcasting and Electronic Media, 43, 327-345.

Cohen, J., \& Metzger, M. (1998). Social affiliation and the achievement of ontological security through interpersonal and mass communication. Critical Studies in Mass Communication, 15(1), 41-60.

Cole, T., \& Leets, L. (1999). Attachment styles and intimate television viewing: Insecurely forming relationships in a parasocial way. Journal of Social and Personal Relationships, 16, 495-511.

Eisenstock, B. (1984). Sex-role differences in children's identification with counterstereotypical televised portrayals. Sex Roles, 10, 417-430.

Erikson, E. (1968). Identity youth and crisis. New York: Norton. 
Fiske, J. (1989). Television culture. London: Routledge.

Flitterman-Lewis, S. (1987). Psychoanalysis, film and television. In R. C. Allen (Ed.), Channels of discourse: Television and contemporary criticism (pp. 172-210). Chapel Hill: University of North Carolina Press.

Freud, S. (1989). An outline of psychoanalysis (J. Strachey, Trans.). New York: Norton. (Original work published 1940)

Gentile, M. (Producer). (2000). Who wants to be a millionaire? New York: American Broadcasting Corporation.

Gleicher, F. (1998). Identification with effective and ineffective others: Evidence for control motivation in dysphoric individuals. Manuscript submitted for publication.

Hoffner, C. (1996). Children's wishful identification and parasocial interaction with favorite television characters. Journal of Broadcasting and Electronic Media, 40, 389-402.

Hoffner, C., \& Buchanan, M. (1998, May). Parasocial interaction and wishful identification with TV characters: The role of perceived character attributes. Paper presented at the meeting of the International Communication Association, Jerusalem.

Hoffner, C., \& Cantor, J. (1991). Perceiving and responding to mass media characters. In J. Bryant \& D. Zillmann (Eds.), Responding to the screen: Reception and reaction processes (pp. 63-103). Hillsdale, NJ: Lawrence Erlbaum Associates, Inc.

Horton, D., \& Wohl, R. R. (1956). Mass communication and para-social interaction. Psychiatry, 19, $215-229$.

Houston, B. (1984, Summer). Viewing television: The metapsychology of endless consumption. Quarterly Review of Film Studies, 9, 183-195.

Huesmann, L. R., Lagerspetz, K., \& Eron, L. D. (1984). Intervening variables in the TV violence-aggression relation: Evidence from two countries. Developmental Psychology, 20, 746-775.

Kelman, H. C. (1961). Processes of opinion change. Public Opinion Quarterly, 25, 57-78.

Liebes, T. (1996). Notes on the struggle to define involvement in television viewing. In J. Hay, L. Grossberg, \& E. Wartella (Eds.), The audience and its landscape (pp. 177-186). Boulder, CO: Westview.

Liebes, T., \& Katz, E. (1990). The export of meaning: Cross-cultural readings of "Dallas." New York: Oxford University Press.

Livingstone, S. M. (1998). Making sense of television: The psychology of audience interpretation. New York: Routledge.

Lombard, M. (1995). Direct responses to people on the screen: Television and personal space. Соттиnication Research, 22, 288-324.

Maccoby, E. E., \& Wilson, W. C. (1957). Identification and observational learning from films. Journal of Abnormal Social Psychology, 55, 76-87.

Mead, G. H. (1934). Mind, self and society. Chicago: University of Chicago Press.

Meyrowitz, J. (1994). The life and death of media friends: New genres of intimacy and mourning. In R. Cathcart \& S. Drucker (Eds.), American heroes in a media age (pp. 62-81). Cresskill, NJ: Hampton.

Miall, D. S., \& Kuiken, D. (1995). Aspects of literary response: A new questionnaire. Research in the Teaching of English, 29(1), 37-58.

Morley, D. (1992). Television, audiences, and cultural studies. London: Routledge.

Newton, B. J., \& Buck, E. B. (1985). Television as significant other: Its relationship to self-descriptors in five countries. Journal of Cross-Cultural Psychology, 16, 289-312.

Newton, B. J., Buck, E. B., \& Woelfel, J. A. (1986). Metric multidimensional scaling of viewers' perception of TV in five countries. Human Organization, 45, 162-170.

Oatley, K. (1994). A taxonomy of the emotions of literary response and a theory of identification in fictional narrative. Poetics, 23, 53-74.

Oatley, K. (1999). Meeting of minds: Dialogue, sympathy, and identification in reading fiction. Poetics, 26, 439-454. 
Petty, R. E., \& Cacioppo, J. T. (1984). The effects of involvement on responses to argument quantity and quality: Central and peripheral routes to persuasion. Journal of Personality and Social Psychology, 46, 69-81.

Press, A. (1989). Class and gender in the hegemonic process: Class differences in women's perceptions of television realism and identification with television characters. Media, Culture and Society, 11, 229-251.

Radway, J. A. (1983). Women read the romance: The interaction of text and context. Feminist Studies, 9(1), 53-78.

Reeves, B., \& Miller, M. M. (1978). A multidimensional measure of children's identification with television characters. Journal of Broadcasting, 22, 71-86.

Rubin, A. M., Perse, E. M., \& Powell, R. A. (1985). Loneliness, parasocial interaction, and local television news viewing. Human Communication Research, 12, 155-180.

Rubin, A. M., \& Rubin, R. B. (1985). Interface of personal and mediated communication: A research agenda. Critical Studies in Mass Communication, 2, 36-53.

Rubin, A. M., \& Rubin, R. B. (1998, May). Interfacing personal and mediated communication: An update. Paper presented to preconference of the International Communication Association, Haifa, Israel.

Rubin, R. B., \& McHugh, M. P. (1987). Development of parasocial interaction relationships. Journal of Broadcasting and Electronic Media, 31, 279-292.

Sheehan, P. W. (1983). Age trends and the correlates of children's television viewing. Australian Journal of Psychology, 35, 417-431.

Steever, G. S. (1994, August). Para-social attachments: Motivational antecedents. Paper presented at the meeting of the American Psychological Association, Los Angeles.

Tajfel, H. (1979). Social categorization, social identity and social comparison. In H. Tajfel (Ed.), Differentiation between social groups (pp. 77-101). London: Academic.

Turner, J. R. (1993). Interpersonal and psychological predictors of parasocial interaction with different television performers. Communication Quarterly, 41, 443-453.

van Beneden, P. (1998). Viewer identification with characters in television and film fiction. Available on the World Wide Web: www.aber.ac.uk/media/functions/mcs.html

Wied, M., Zillmann, D., \& Ordman, V. (1994). The role of empathic distress in the enjoyment of cinematic tragedy. Poetics, 23, 61-106.

Wiegman, O., Kuttschreuter, M., \& Baarda, B. (1992). A longitudinal study of the effects of television viewing on aggressive and prosocial behaviors. British Journal of Social Psychology, 31, 147-164.

Wilson, T. (1993). Watching television. Cambridge, England: Polity.

Wollheim, R. (1974). Identification and imagination. In R. Wollheim (Ed.), Freud: A collection of critical essays (pp. 172-195). New York: Anchor/Doubleday.

Zillmann, D. (1994). Mechanisms of emotional involvement with drama. Poetics, 23, 33-51. 
Copyright of Mass Communication \& Society is the property of Lawrence Erlbaum Associates and its content may not be copied or emailed to multiple sites or posted to a listserv without the copyright holder's express written permission. However, users may print, download, or email articles for individual use. 